\title{
Evaluation of Number of Leaves/Plant of Wheat Crop as Influenced by Different Irrigation Methods and Frequency of Irrigation
}

\author{
Yogesh Kumar Sahu* and Pawan Sirothiya \\ Mahatma Gandhi Chitrakoot Gramodaya Vishwa Vidyalaya, \\ Chitrakoot, District Satna, Madhya Pradesh, India \\ *Corresponding author
}

\section{A B S T R A C T}

\begin{tabular}{|l|}
\hline Ke y w o r d s \\
Irrigation, \\
Harvest, Stage \\
and Wheat
\end{tabular}

The experiment was carried out to find out the Evaluation of Number of leaves/plant of wheat crop as influenced by different irrigation methods and frequency of irrigation. The treatments comprised of two irrigation methods, four irrigation frequencies were evaluated in RBD (factorial) design with three replications. The four times irrigations given to wheat crop at CRI, tillering, Jointing and milking stages resulted in almost significantly higher number of leaves/plant at every stage of observations i.e. from 30 DAS up to the harvest stage. The second and third best irrigation scheduling was three and then the times Irrigation scheduling was three and then two times irrigation.

\section{Introduction}

Wheat (Triticum aestivum L.) is one of the leading cereals in the world. It belongs to the family Gramineae and it is the world's most widely cultivated cereal crop which ranks first followed by rice. It ranks first both in acreage and production among the grain crops of the world (FAO, 2008). BARI (2006) also reported that wheat grain is rich in food value containing $12 \%$ protein, $1.72 \%$ fat, $69.60 \%$ carbohydrate and $27.20 \%$ minerals.
It is essential that the water use efficiency (WUE) of winter wheat be improved, while maintaining, or potentially increasing, grain yields.

For example, the North China Plain occupies $39 \%$ of the country's cultivated area; but only has $8 \%$ of the nation's water resources, and this water shortage has seriously restricted the development of winter wheat production. Determining a suitable irrigation frequency is an important step in being able to optimize 
winter wheat yield and WUE. Irrigation frequency can affect plant growth in various ways. Decreased irrigation frequency is an important technique used to improve WUE of paprika Shin JH et al., (2012) and citrus García-Tejero I et al., (2011). In winter wheat, increased irrigation frequency results in low evapotranspiration Li QQ, Lang $\mathrm{K}$ et al., 2013. Han et al., (2014) revealed that by irrigating twice in the winter wheat growing season, grain yield could be increased; however, irrigation timing at the end of the growing season could decrease grain yield.

Similarly, Li et al., 2010 revealed that frequent irrigation late in the winter wheat growing season decreased WUE, and this was mainly due to changes in the vertical distribution of root density. Previous studies also suggested that, for winter wheat, a onetime irrigation of $120 \mathrm{~mm}$ could produce a reasonable grain yield and WUE, and irrigation $(60 \mathrm{~mm})$ at both the jointing and heading stages significantly improved WUE Li QQ, Bian CY et al., 2015, Li QQ et al., 2011, Naresh RK et al., 2012.

Planting pattern also plays an important role in improving grain yield and WUE. Research in North India revealed that planting pattern could significantly increase both winter wheat and summer maize (Zea mays L.) grain yield and WUE Naresh RK et al., 2012. In a North China study, furrow planting significantly increased winter wheat grain yield and WUE under water deficit conditions Li QQ et al., 2010.

In addition, partial root zone irrigation was found to affect the growth and WUE of crops. Parsad (1993) in the field conducted on silty lome found that combination of manual weed control + irrigation at $150 \mathrm{~mm} \mathrm{CPE}+150 \mathrm{~kg}$ $\mathrm{N}$ achieved the greatest wheat grain yields. Abd El- Gawad el al. (1994) found that increasing number of irrigation from two to four increased wheat growth and seed index; while Ibrahim et al., and Khaatun et al., (2007).

\section{Materials and Methods}

A field experiment on different methods of irrigation and stages of irrigation on growth wheat (Triticum aestivam L.) was carried out during the year 2016-2017 and 2017-2018 at the Instructional Farm, MGCGVV, Chitrakoot, Satna (M.P.). The research work was conducted in the Randomized Block Design with three replications. Each replication was comprised of 08 treatment combinations. In different treatments combination of $\mathrm{T}_{0}$ Control, $\mathrm{T}_{1} 1$ Irrigation surface (CRI stage), $\mathrm{T}_{2} 2$ Irrigation surface (CRI + Jointing stage), $\mathrm{T}_{3} 3$ Irrigation surface (CRI +Jointing + Milking stage), $\mathrm{T}_{4} 4$ Irrigation surface (CRI +Tillering +Jointing + Milking stage), $\mathrm{T}_{5} 1$ Irrigation sprinkler (CRI stage), $\mathrm{T}_{6} 2$ Irrigation sprinkler (CRI +Jointing stage), $\mathrm{T}_{7} 3$ Irrigation sprinkler (CRI +Jointing +Milking stage), $\mathrm{T}_{8} 4$ Irrigation sprinkler (CRI +Tillering +Jointing +Milking stage).

The Chitrakoot is situated in semi-arid and sub-tropical zone of Kymore Plateau \&Satpuda Hills of Madhya Pradesh, North of $24^{0} 31^{\prime}$ latitude and East of $81^{\circ} 15^{\prime}$ longitude with an altitude of $306 \mathrm{~m}$ from mean sea level. The soil of the investigation field was clay loam with good drainage and uniform texture with medium NPK status. Observations were recorded according to standard procedure on Number of leaves/plants.

\section{Results and Discussion}

\section{Number of leaves/plant}

This parameter was observed periodically throughout the plant growth from 40,40 and 90 DAS and the data so obtained have been summarized in Table 1 to 4. 
Table.1 Number of leaves / plant of wheat as influenced by different methods and frequency of irrigation

\begin{tabular}{|c|c|c|c|c|c|c|c|c|c|}
\hline \multirow[t]{2}{*}{ Treatments } & \multicolumn{3}{|c|}{40 DAS } & \multicolumn{3}{|c|}{60 DAS } & \multicolumn{3}{|c|}{90 DAS } \\
\hline & 2016-17 & 2017-18 & Mean & 2016-17 & 2017-18 & Mean & 2016-17 & 2017-18 & Mean \\
\hline \multicolumn{10}{|c|}{ Methods of irrigation } \\
\hline Surface & 12.88 & 15.93 & 14.40 & 40.36 & 41.10 & 40.73 & 47.25 & 49.84 & 48.54 \\
\hline Sprinkle & 13.61 & 16.38 & 14.99 & 42.03 & 41.94 & 41.98 & 49.84 & 52.74 & 51.29 \\
\hline S. Em \pm & 0.49 & 0.54 & 0.52 & 1.69 & 0.58 & 1.14 & 1.79 & 0.42 & 1.11 \\
\hline $\mathrm{CD}(\mathrm{P}=0.05)$ & N S & N S & N S & N S & N S & N S & N S & 1.18 & N S \\
\hline \multicolumn{10}{|c|}{ Frequency of irrigation } \\
\hline CRI stage & 11.36 & 14.66 & 13.01 & 31.65 & 33.85 & 32.75 & 38.57 & 40.66 & 39.61 \\
\hline $\begin{array}{l}\text { CRI+ jointing } \\
\text { stages }\end{array}$ & 13.29 & 15.11 & 14.20 & 38.30 & 37.30 & 37.80 & 46.40 & 48.35 & 47.37 \\
\hline $\begin{array}{l}\text { CRI +Jointing } \\
\text { +Milking stages }\end{array}$ & 13.93 & 17.22 & 15.57 & 44.84 & 41.11 & 42.97 & 51.98 & 55.69 & 53.83 \\
\hline $\begin{array}{l}\text { CRI+ tillering } \\
\text { +jointing + milk. } \\
\text { stages }\end{array}$ & 14.41 & 17.65 & 16.03 & 49.98 & 53.83 & 51.90 & 57.24 & 60.48 & 58.86 \\
\hline S.E m \pm & 0.35 & 0.38 & 0.37 & 1.19 & 0.41 & 0.80 & 1.20 & 0.30 & 0.75 \\
\hline $\mathrm{CD}(\mathrm{P}=0.05)$ & 0.99 & 1.08 & 1.04 & 3.37 & 1.17 & 2.27 & 3.40 & 0.84 & 2.12 \\
\hline Interaction & $\mathbf{N ~ S}$ & $\mathbf{N} \mathbf{S}$ & $\mathbf{N S}$ & $\mathbf{N ~ S}$ & Sig. & $\mathbf{N ~ S ~}$ & $\mathbf{N ~ S}$ & Sig & $\mathbf{N} \mathbf{S}$ \\
\hline
\end{tabular}


Table.2 Number of leaves/plant at 40 DAS of wheat as influenced by different methods and frequency of irrigation

\begin{tabular}{|c|c|c|c|}
\hline \multirow[t]{3}{*}{ Frequency of irrigation } & \multirow{2}{*}{\multicolumn{2}{|c|}{$\begin{array}{c}\text { Methods of irrigation } \\
2016-17\end{array}$}} & \multirow[t]{3}{*}{ Mean } \\
\hline & & & \\
\hline & Surface & Sprinkler & \\
\hline Surface irrigation CRI stage & 10.80 & 11.93 & 11.36 \\
\hline CRI+ jointing stage & 13.07 & 13.51 & 13.29 \\
\hline $\begin{array}{l}\text { CRI+ jointing }+ \text { milking } \\
\text { stages }\end{array}$ & 13.67 & 14.18 & 13.93 \\
\hline $\begin{array}{l}\text { CRI+ tillering } \quad \text { +jointing } \\
\text { +milking stages }\end{array}$ & 13.99 & 14.82 & 14.41 \\
\hline Mean & 12.88 & 13.61 & 13.24 \\
\hline & quency of & 17-18 & \\
\hline $\begin{array}{l}\text { Sprinkler irrigation } \\
\text { stage }\end{array}$ & 14.62 & 14.69 & 14.66 \\
\hline CRI+ jointing stages & 14.72 & 15.50 & 15.11 \\
\hline $\begin{array}{l}\text { CRI+ jointing }+ \text { milking } \\
\text { stages }\end{array}$ & 17.18 & 17.25 & 17.22 \\
\hline $\begin{array}{l}\text { CRI+ tillering }+ \text { jointing } \\
+ \text { milking stages }\end{array}$ & 17.20 & 18.10 & 17.65 \\
\hline Mean & 15.93 & 16.38 & 16.15 \\
\hline
\end{tabular}

\begin{tabular}{|c|c|c|c|c|}
\hline Year & & Methods of irrigation & Stage of irrigation & Interaction \\
\hline \multirow{2}{*}{$\mathbf{2 0 1 6 - 1 7}$} & S. Em \pm & 0.49 & 0.35 & 0.70 \\
\cline { 2 - 5 } & CD 5\% & N S & 0.99 & N S \\
\hline \multirow{2}{*}{$\mathbf{2 0 1 7 - 1 8}$} & S.E m \pm & 0.54 & 0.38 & 0.76 \\
\cline { 2 - 5 } & CD 5\% & N S & 1.08 & N S \\
\hline
\end{tabular}


Table.3 Number of leaves/plant at 60 DAS of wheat as influenced by different methods and frequency of irrigation

\begin{tabular}{|c|c|c|c|}
\hline \multirow[t]{3}{*}{ Frequency of irrigation } & \multirow{2}{*}{\multicolumn{2}{|c|}{$\begin{array}{c}\text { Methods of irrigation } \\
2016-17\end{array}$}} & \multirow[t]{3}{*}{ Mean } \\
\hline & & & \\
\hline & Surface & Sprinkler & \\
\hline Surface irrigation CRI stage & 29.89 & 33.41 & 31.65 \\
\hline CRI \& jointing stages & 28.23 & 38.37 & 38.30 \\
\hline $\begin{array}{l}\text { CRI+ jointing + milking } \\
\text { stages }\end{array}$ & 43.51 & 46.17 & 44.84 \\
\hline $\begin{array}{l}\text { CRI+ tillering+ Jointing + } \\
\text { milking stages }\end{array}$ & 49.79 & 50.16 & 49.98 \\
\hline Mean & 40.36 & 42.03 & 41.19 \\
\hline Frequency of irrigation & & $17-18$ & \\
\hline $\begin{array}{l}\text { Sprinkler irrigation CRI } \\
\text { stage }\end{array}$ & 30.16 & 37.53 & 33.85 \\
\hline CRI \& jointing stages & 37.32 & 37.29 & 37.30 \\
\hline $\begin{array}{l}\text { CRI+ Jointing + milking } \\
\text { stages }\end{array}$ & 45.19 & 37.03 & 41.11 \\
\hline $\begin{array}{l}\text { CRI+ tillering+ Jointing + } \\
\text { milking stages }\end{array}$ & 51.75 & 55.90 & 53.83 \\
\hline Mean & 41.10 & 41.94 & 41.52 \\
\hline
\end{tabular}

\begin{tabular}{|c|c|c|c|c|}
\hline Year & & Methods of irrigation & Stage of irrigation & Interaction \\
\hline \multirow{2}{*}{$\mathbf{2 0 1 6 - 1 7}$} & S. Em \pm & 1.69 & 1.19 & 2.38 \\
\cline { 2 - 5 } & CD 5\% & N S & 3.37 & N S \\
\hline \multirow{2}{*}{$\mathbf{2 0 1 7 - 1 8}$} & S.E m \pm & 0.58 & 0.41 & 0.82 \\
\cline { 2 - 5 } & CD 5\% & N S & 1.17 & 2.39 \\
\hline
\end{tabular}


Table.4 Number of leaves / plant at 90 DAS of wheat as influenced by different methods and frequency of irrigation

\begin{tabular}{|l|c|c|c|}
\hline \multirow{2}{*}{ Frequency of irrigation } & \multicolumn{2}{|c|}{ Methods of irrigation } & \multirow{2}{*}{ Mean } \\
\cline { 2 - 4 } & \multicolumn{2}{|c|}{ Surface } & \multicolumn{1}{|c|}{ Sprinkler } \\
\hline Surface Irrigation CRI stage & 36.11 & 41.04 & 38.57 \\
\hline CRI+ jointing stages & 45.86 & 46.93 & 46.40 \\
\hline $\begin{array}{l}\text { CRI+ Jointing + milking } \\
\text { stages }\end{array}$ & 50.56 & 53.39 & 51.98 \\
\hline $\begin{array}{l}\text { CRI+ tillering+ jointing + } \\
\text { milking stages }\end{array}$ & 56.48 & 58.01 & 57.24 \\
\hline Mean & 47.25 & 49.84 & 48.54 \\
\hline Frequency of irrigation & 38.19 & 43.13 & 40.66 \\
\hline $\begin{array}{l}\text { Sprinkler irrigation CRI } \\
\text { stage }\end{array}$ & 47.42 & 49.28 & 48.35 \\
\hline CRI +jointing stages & 54.11 & 57.26 & 55.69 \\
\hline $\begin{array}{l}\text { CRI+ jointing + milking } \\
\text { stages }\end{array}$ & 59.64 & 61.31 & 60.48 \\
\hline $\begin{array}{l}\text { CRI+ tillering+ jointing + } \\
\text { milking stages }\end{array}$ & 49.84 & 52.74 & 51.29 \\
\hline Mean & & & \\
\hline
\end{tabular}

\begin{tabular}{|c|c|c|c|c|}
\hline Year & & Methods of irrigation & Stage of irrigation & Interaction \\
\hline \multirow{2}{*}{$\mathbf{2 0 1 6 - 1 7}$} & S.Em \pm & 1.79 & 1.20 & 2.40 \\
\cline { 2 - 5 } & CD 5\% & N S & 3.40 & N S \\
\hline \multirow{2}{*}{$\mathbf{2 0 1 7 - 8}$} & S.E m \pm & 0.42 & 0.30 & 0.59 \\
\cline { 2 - 5 } & CD 5\% & 1.18 & 0.84 & 1.80 \\
\hline
\end{tabular}


The enhancement in leaves/plant, in general, was taken place with the advance inclement of plant growth till 90 DAS stage of observations. The leaves formation was very fast between 40 and 60 DAS stage of plant growth. There after the rise was allow up to 90 DAS stage. At 40 DAS stage, the leaves count in various treatments ranged from 13.01 to $16.03 /$ plant, at $60 \mathrm{DAS} 33.85$ to 53.83 /plant whereas at $90 \mathrm{DAS}$, it ranged from 39.61 to $58.86 /$ plant based on two years mean values.

As regards with the effect of methods and frequency of irrigation, the four irrigations gave at CRI, tillering, jointing and milking stages ensued in remarkably higher leaves/plant at every stage of observations in both the years. The maximum number of leaves formation at 40,60 and 90 DAS stage was 16.03, 51.90 and 58.86/plant, respectively. However the second best treatment was three irrigations given at CRI, jointing and milking stages of plant growth and development. On the other hand, almost significantly by minimum leaves formation /plant was recorded when only one irrigation was given at CRI stage the leaves count being 13.01, 32.75 and 39.61/plant at the respective stages. These values are based on two years experimentation. The scouting of data in Table 1 to 4 evidently reveal that the treatment interactions between procedures and frequency of irrigation was observed to be extraneous at every stage of observations.

\section{Discussion}

The results of present experiment that the four times irrigation given to wheat crop at CRI, tillering, jointing and milking stages resulted in almost significantly higher leaves per plant at all the stage of observations i.e. from 30, 60, 90 DAS and harvest stage. The second and third best irrigation scheduling was three and then two times irrigation. Whereas only one irrigation given at CRI stage brought about the significantly decreased plant height and leaves formation per plant. Similarly at 90 DAS, maximum leaves/plant were 58.86 as against only 39.61 leaves plant under one irrigation, The higher irrigation frequency might have provided desirable condition for water movement in soil and for uptake by roots (Segal et al., 2000). The sufficient water availability at all the four critical(waterdemanding)stages provided most favourable conditions to absorbed required nutrients for the proper root shoot growth and development of plant all any with sufficient production of photosynthates. The present results agree with those of many researchers (Kahlown et al., 2007, Mantazav et al., 2008, Dukes et al., 2010, Davk et al., 2016 and Sarkar et al., 2017).

The four times irrigations given to wheat crop at CRI, tillering, jointing and milking stages resulted in almost significantly higher leaves per plant at every stage of observations i.e. from 30 DAS up to the harvest stage. The second and third best irrigation scheduling was three and then the times Irrigation scheduling was three and then two times irrigation. Whereas only the one irrigation given at CRI stage brought about the significantly decreased leaves formation per plant. Accordingly at harvest stage, Similarly at 90 DAS, maximum leaves were 58.86/plant as against only 39.61 leaves plant under one irrigation.

\section{References}

Abd El-Gawad, A.A., S. El-Habbal, A.S.A. Edris and A.D. El-Ham. 1994. Effect of water stress during grain filling and nitrogen fertilizer on chemical composition and technological properties of wheat plants. Egyptian J. Appl. Sci. 9: 216-232.

BARI (Bangladesh Agricultural Research Institute). 2006. Annual report for 2005. 
Bangladesh April. Res. Inst. Joydebpur, Gazipur, Bangladesh. pp. 22-23.

FAO (Food and Agriculture Organization). 2008. Production Year Book. Food and Agriculture Organization. Rome. 68: 115.

García-Tejero I, Durán-Zuazo VH, MurielFernández JL, Martínez-García G, Jiménez-Bocanegra JA. Benefits of low-frequency irrigation in citrus orchards. Agron Sustain. Dev. 2011; 31(4): 779-791.

Han HF, Li QQ, Dong BD. Effects of irrigation frequency and stages on grain yield and quality characteristics of winter wheat. Acta Ecol. Sin. 2010; 30(6): 1548-1555.

Hu TT, Kang SZ, Li FS, Zhang JH. Effects of partial root-zone irrigation on the nitrogen absorption and utilization of maize. Agr. Water Manage.2009; 96: 208-214.

Khatun, M.R., A.M.S. Alam and M.R. Amin. 2007. Effect of irrigation on yield and its components in five varieties of wheat (Triticum aestivum L.). Int. J. Sustain. Agric. Technol, 3: 1-6.

Li QQ, Lang K, Liu QR, Bian CY, Liu XH, Chen GQ. Dry matter, grain yield, and evapotranspiration of winter wheat under deficit irrigation in North China Plain. J. Food Agr. Environ. 2013; 11: 2593-3596.

Li QQ, Dong BD, Qiao YZ, Liu MY, Zhang JW. Root growth, available soil water, and water-use efficiency of winter wheat under different irrigation regimes applied at different growth stages in North China. Agr. Water Manage. 2010; 97(10): 1676-1682.

Li QQ, Bian CY, Liu XH, Ma CJ, Liu QR. Winter wheat grain yield and water use efficiency in wide-precision planting pattern under deficit irrigation in North China Plain. Agr. Water Manage. 2015; 153: 71-76.

Li QQ, Shen JY, Zhao DD. Effect of irrigation frequency on yield and leaf water use efficiency of winter wheat. Tran. CSAE 2011; 27(3): 33-36.

Naresh RK, Singh SP, Chauhan P. Influence of conservation agriculture, permanent raised bed planting and residue management on soil quality and productivity in maize-wheat system in western Uttar Pradesh. Int. J. Life Sci. Biote. 2012; 1(4): 27-34.

Parsad, K. 1993. Effect of irrigation and nitrogen on the efficiency of weed management in wheat. Integrated weed management for sustainable agriculture Proc. of Indian Soc. of Weed Sci. Int'1. Symposium, India. Vol. III, 71-74.

Shin JH, Noh EH, Son JE. Transpiration, growth, and water use efficiency of paprika plants (Capsicum annuum L.) as affected by irrigation frequency. Hortic. Environ. Biote. 2012; 53(2): 129-134.

Yactayo W, Ramírez DA, Gutiérrez R, Mares V, Posadas A, Quiroz R. Effect of partial root-zone drying irrigation timing on potato tuber yield and water use efficiency. Agr. Water Manage.2013; 123: 65-70.

\section{How to cite this article:}

Yogesh Kumar Sahu and Pawan Sirothiya. 2020. Evaluation of Number of Leaves/Plant of Wheat Crop as Influenced by Different Irrigation Methods and Frequency of Irrigation. Int.J.Curr.Microbiol.App.Sci. 9(10): 3627-3634. doi: https://doi.org/10.20546/ijcmas.2020.910.420 